\title{
Eimeria infections in goats in Southern Portugal
}

\author{
Infeçóes por Eimeria em caprinos do Sul de Portugal \\ Liliana Machado Ribeiro da Silva ${ }^{1,2 *}$; Maria João Martins Vila-Viçosa' ${ }^{1}$ Telmo Nunes ${ }^{3}$; Anja Taubert²; \\ Carlos Hermosilla ${ }^{2}$; Helder Carola Espiguinha Cortes $^{1}$
}

\begin{abstract}
${ }^{1}$ Núcleo da Mitra, Instituto de Ciências Agrárias e Ambientais Mediterrânicas - ICAAM, Instituto de Investigação e Formação Avançada - IIFA, Universidade de Évora - UEVORA, Évora, Portugal

${ }^{2}$ Institute of Parasitology, Faculty of Veterinary Medicine, Justus Liebig University Giessen - JLU, Giessen, Germany

${ }^{3}$ Centro Interdisciplinar de Investigação em Sanidade Animal - CIISA, Faculdade de Medicina Veterinária - FMV,

Universidade Técnica de Lisboa - UTL, Lisboa, Portugal
\end{abstract}

Received November 28, 2013

Accepted May 13, 2014

\begin{abstract}
Coccidiosis caused by Eimeria species is a major form of intestinal infection affecting intensively and semi-intensively reared goats. The province of Alentejo is the main goat-producing area in Portugal. Therefore, all 15 Serpentina goat farms in Alentejo were analyzed regarding the occurrence and diversity of Eimeria species. Fecal samples obtained from 144 animals (52.1\% dairy goats, $47.9 \%$ pre-pubertal goats) were examined using the modified McMaster technique to determine the number of oocysts per gram of feces. Eimeria spp. oocysts were present in $98.61 \%$ of the fecal samples and, overall, nine different Eimeria species were identified. The most prevalent species were E. ninakoblyakimovae (88\%) and E. arloingi (85\%), followed by E. alijevi (63\%) and E. caprovina (63\%). The average number of oocysts shed was significantly lower in dairy goats than in pre-adult animals. Astonishingly, no clinical signs of coccidiosis were observed in any of the animals examined, even though they were shedding high numbers of oocysts and were infected with highly pathogenic species. Thus, implementation of routine diagnostic investigation of the occurrence and diversity of caprine Eimeria species may be a useful tool for determination and better understanding of their potential economic impact on goat herds in southern Portugal.
\end{abstract}

Keywords: Eimeria, coccidiosis, goats, infection, Portugal.

\section{Resumo}

A coccidiose causada por espécies de Eimeria é a maior infecção intestinal que afeta regimes intensivos e semiintensivos de caprinos. A região do Alentejo é a mais importante na indústria caprina em Portugal. Assim, todas as 15 exploraçóes de caprinos da raça Serpentina do Alentejo foram analisadas para determinar a frequência e diversidade de espécies de Eimeria presentes. Amostras fecais de 144 animais (52,1\% adultas, 47,9\% jovens) foram examinadas com a técnica de McMaster modificada para determinar o número de oocistos por grama de fezes. Oocistos de Eimeria spp. estavam presentes em $98,61 \%$ das amostras fecais e nove espécies distintas foram identificadas. As espécies mais frequentes foram E. ninakohlyakimovae (88\%) e E. arloingi (85\%), seguidas por E. alijevi (63\%) e E. caprovina (63\%). A média do número de oocistos excretados foi significativamente menor em adultas do que em jovens. Surpreendentemente, não foram observados quaisquer sinais clínicos em nenhum dos animais examinados, apesar de eliminarem elevados números de oocistos e de estarem infectados com espécies altamente patogénicas. A prática de diagnósticos de rotina para identificaçáo de espécies de Eimeria caprinas pode ser um importante instrumento para o melhor entendimento do nefasto impacto da doença em exploraçôes de caprinos no Sul de Portugal.

Palavras-chave: Eimeria, coccidiosis, caprinos, infecção, Portugal.

\section{Introduction}

Caprine coccidiosis caused by the apicomplexan protozoan genus Eimeria is a worldwide and frequent intestinal parasitosis of goats (NORTON, 1986; O’CALLAGHAN, 1989; AGYEI et al.,

${ }^{*}$ Corresponding author: Liliana Machado Ribeiro da Silva

Institut für Parasitologie, Schubert Str 81, 35392 Giessen, Germany

e-mail: lilianasilva.mv@gmail.com
2004). It affects the profitability of the industry, particularly in rural, semi-arid geographic regions that are economically dependent on goat rearing, such as the Mediterranean basin (RUIZ et al., 2006), Africa (KANYARI, 1993), Asia (FAIZAL; RAJAPAKSE, 2001) and Latin America (CAVALCANTE et al., 2012). Economic losses result from the high mortality rate among goat kids, reduction 
of productivity and delayed weight gains of parasitized animals (LIMA, 2004; RUIZ et al., 2012).

Goats of all ages are in principle susceptible to Eimeria spp. infections, but younger animals are more likely to develop the disease (TAYLOR; CATCHPOLE, 1994). Depending on the type of management, caprine coccidiosis might affect $100 \%$ of goat kids within the age range of 4-10 weeks, thus directly affecting animal health and the profitability of the goat industry (KOUDELA; BOKOVÁ, 1998; RUIZ et al., 2010). Eimeria-infected goat kids show clinical signs particularly during the weaning period, ranging from non-hemorrhagic to severe hemorrhagic diarrhea, with accompanying weight loss, dehydration and growth delay (KOUDELA; BOKOVÁ, 1998; RUIZ et al., 2006, 2012).

Although goats can be parasitized by 16 different Eimeria species, most of them do not cause visible clinical coccidiosis. Therefore, diagnosis must be combined with species identification in order to avoid economic losses. Eimeria ninakohlyakimovae and $E$. arloing $i$ are considered to be the most pathogenic species (KOUDELA; BOKOVÁ, 1998; CHARTIER; PARAUD, 2012).

During the last two decades, there has been remarkable growth in the goat industry and currently about one billion goats are being reared for meat and milk production worldwide. It is evident that the goat industry is not only playing a big role in the nutritional security of small farmers in many poor countries but also assures working opportunities for a sizeable population around the world. This particular feature of the goat industry also includes Portugal. Approximately half a million goats are kept in this country, which represents the sixth largest national goat industry within the European Union (GPP, 2009). In Portugal, goats are usually raised in extensive or semi-extensive systems, mostly in semi-arid geographic regions with poor soil conditions and a lack of vegetation apart from some bushes. These environments are not appropriate for rearing other domestic animals. Thus, goats play an important role in stabilizing and maintaining rural communities, thereby avoiding the abandonment of these poor regions by the human population. The most important Portuguese province for the goat population is Alentejo, where $21.6 \%$ of all Portuguese goats are kept (GPP, 2009). Of the six native Portuguese goat breeds, the Serpentina breed is the one at risk of extinction, according to the IUCN Red List threatened categories (IUCN, 2013), since there are fewer than 5,000 pure mature individuals (APCRS, 2014) in existence. Several efforts have been made in the past years to maintain this breed, including financial support from national and European programs like the PRODER program (PRODER, 2011). Serpentina goats are well adapted to semi-arid climate conditions and are used for both milk and meat production. Nevertheless, semi-intensive and intensive systems of goat rearing provide excellent environmental conditions for accumulation and transmission of Eimeria oocysts and, in the absence of effective control measures, clinical coccidiosis is the inevitable outcome (RUIZ et al., 2006). There are, however, records in some herds of deaths among kids around the weaning period, which have reached $20 \%$ of newly born animals and have been correlated with coccidiosis (APCRS, personal communication). Therefore, in the present study, we concentrated on this special goat breed and examined 15 Serpentina goat herds for the presence, diversity and parasite load of Eimeria species, considering both dairy goats
( $>1$ year) and pre-pubertal goats (5-12 months of age). The overall aim of this survey was to characterize Eimeria spp. infections and identify species occurring in the southern part of Portugal using classical coprological methods of diagnosis in dairy goat herds, so as to gain better understanding of caprine coccidiosis epidemiology in semi-arid areas.

\section{Materials and Methods}

This study was carried out in the province of Alentejo, which comprises one third of the total area of Portugal, covering $31,604.9 \mathrm{~km}^{2}$ area, with an average altitude of $200 \mathrm{~m}$ (INE, 2010). The Serpentina goat farms were distributed throughout Alentejo. The climate is semi-arid with hot and dry summers but damp and cold winters; the average rainfall is less than $700 \mathrm{~mm}$ per year. The rainy season lasts from late autumn to early spring. There are currently 15 Serpentina goat herds in this region; all of them present semi-extensive production systems. More than $70 \%$ are medium-sized farms keeping more than 200 dairy goats. There are two breeding seasons: one in autumn (September-October) and another in winter (January-February). Male goat kids are mainly sold for meat consumption during the Christmas and Easter periods, while some female goat kids are kept for replacement, when presenting exceptional phenotypic characteristics.

Fecal samples were collected rectally from 144 goats. All fecal samples were placed in plastic bags and kept at $4{ }^{\circ} \mathrm{C}$ until coprological analyses were performed, which was done at the Victor Caeiro Parasitology Laboratory, University of Évora, Portugal. The fecal samples were classified into two categories: dairy goats $(n=75)$ and pre-pubertal goats $(n=69)$.

For each farm, the total number of animals, distribution according to age, number and schedule of anthelminthic or anti-coccidial treatments and place of birth were surveyed. The two categories of animals were grouped as follows: pre-pubertal goats (group 1: 5-12 months of age) and dairy goats (group 2, split into three age groups: 2-4 (2a), 5-7 (2b) and 8-11 (2c) year old animals). Individual fecal samples from five animals per group from each herd were taken from the rectum and each animal was checked for common clinical signs relating to coccidiosis (diarrhea, dirty posteriors and dehydration). The numbers of oocysts per gram of feces (OPG) were determined by means of the modified McMaster technique (THIENPONT et al., 1979).

Morphological identification of Eimeria oocysts was carried out based on shape and size of the oocysts, presence or absence of the micropyle and polar cap and color and thickness of oocyst walls (LEVINE, 1985; ECKERT et al., 1995). Oocysts and oocyst sporogony were collected as previously described (HERMOSILLA et al., 2002). Oocysts were isolated from the feces by means of saturated sugar solution $(1.3 \mathrm{~g} / \mathrm{l}$ density) and the suspension was transferred into Petri dishes covered with small glass panels. Oocysts that bonded to the glass panels were washed off with water and were added to $2 \%(\mathrm{w} / \mathrm{v})$ potassium dichromate solution to allow complete sporulation, at room temperature and with regular aeration for 2-5 days. After concentration, simple flotation using saturated saline solution $(1.20 \mathrm{~g} / \mathrm{l})$ was performed 
and the oocysts were observed and measured under a microscope to determine the relative frequency of each species.

Fecal oocyst counts were transformed into the logarithm of OPG plus one $[\log (\mathrm{OPG}+1)]$ to obtain normal distribution. Levene's test, Student's t test, and one-way ANOVA were used to analyze the data $\left(\mathrm{R}^{\oplus}\right.$ software, version 2.13 .1$)$ and determine whether any differences were significant; $p<0.05$ was accepted as a statistically significant difference.

Additionally, due to an unexpected event, histopathological sections were produced from intestinal samples from a kid that died due to coccidiosis in one of the farms. During the necropsy, intestinal tissue samples from the duodenum, jejunum and ileum were collected, fixed in $10 \%$ buffered formalin, embedded in paraffin, sectioned at $5 \mu \mathrm{m}$ and stained with hematoxylin-eosin for observation under an optical microscopic.

\section{Results}

As the survey revealed, most of the Serpentina goat farms (80\%) subjected all animals to anthelminthic treatments every six months, medicating with a combination of either benzimidazoles and macrocyclic lactones or benzimidazoles and salicylanilides. Only two goat farms had a metaphylactic program for coccidiosis control, in which kids were treated orally with a single dose of diclazuril (Vecoxan ${ }^{\circledR}$, Virbac, Portugal) at two weeks of age. Generally, parturition occurred on the pasture and kids were fed by natural lactation and were kept together with the dairy goats until weaning and slaughtering time (about two month of age).

Eimeria spp. oocysts were detected in $98.6 \%$ of the fecal samples: 74 samples originating from adult dairy goats and 68 from pre-pubertal animals. In total, nine different Eimeria species were identified in the present study. The most prevalent species were E. ninakohlyakimovae (88\%), followed by E. arloingi (85\%), E. alijevi (63\%) and E. caprovina (63\%). Other species observed less frequently were E. hirci, E. caprina, E. jolchijevi, E. christenseni and E. apsheronica, which were present in 52, 52, 49,39 and $26 \%$ of the samples, respectively. The most prevalent species in dairy goats was E. ninakohlyakimovae, while in preadults $E$. arloingi was found most frequently. Two to five different Eimeria species were observed simultaneously in the feces, thus indicating concomitant infections in more than $50 \%$ of the samples (Figure 1). Furthermore, 6-9 different species were present in more than $40 \%$ of the samples.

Overall, OPG counts varied greatly, ranging from $3.3 \times 10$ to $3.4 \times 10^{5}$. Within the same goat herd and at the same sampling time, pre-pubertal OPGs ranged from $2.6 \times 10^{3}$ to $3.4 \times 10^{5}$. The mean number of oocysts shed was significantly higher $(p<0.001)$ in pre-pubertal goats $(11,358 \pm 49,754)$ than in adult dairy goats (996 $\pm 1,066)$. In contrast, no significant differences were detected between the different dairy goat age ranges (groups 2a-c). Despite high OPG counts, no diarrhea, dirty posteriors or dehydration, which are commonly associated with caprine coccidiosis, were detected in any animal included in the current study.

The mean OPG counts for each farm sampled in the two goat classes are represented in Figure 2. Pre-pubertal goats had significantly higher OPG counts, except for herd number 10, in which one of the pre-pubertal animals showed no oocysts in the feces. Differences in OPG values, in comparing dairy goats between herds, were highly significant $(p<0.001)$. This also held true for pre-pubertal groups $(P<0.001)$.

Additionally, in one of the farms, a two-month-old goat kid suffering from severe coccidiosis presented yellowish diarrhea and

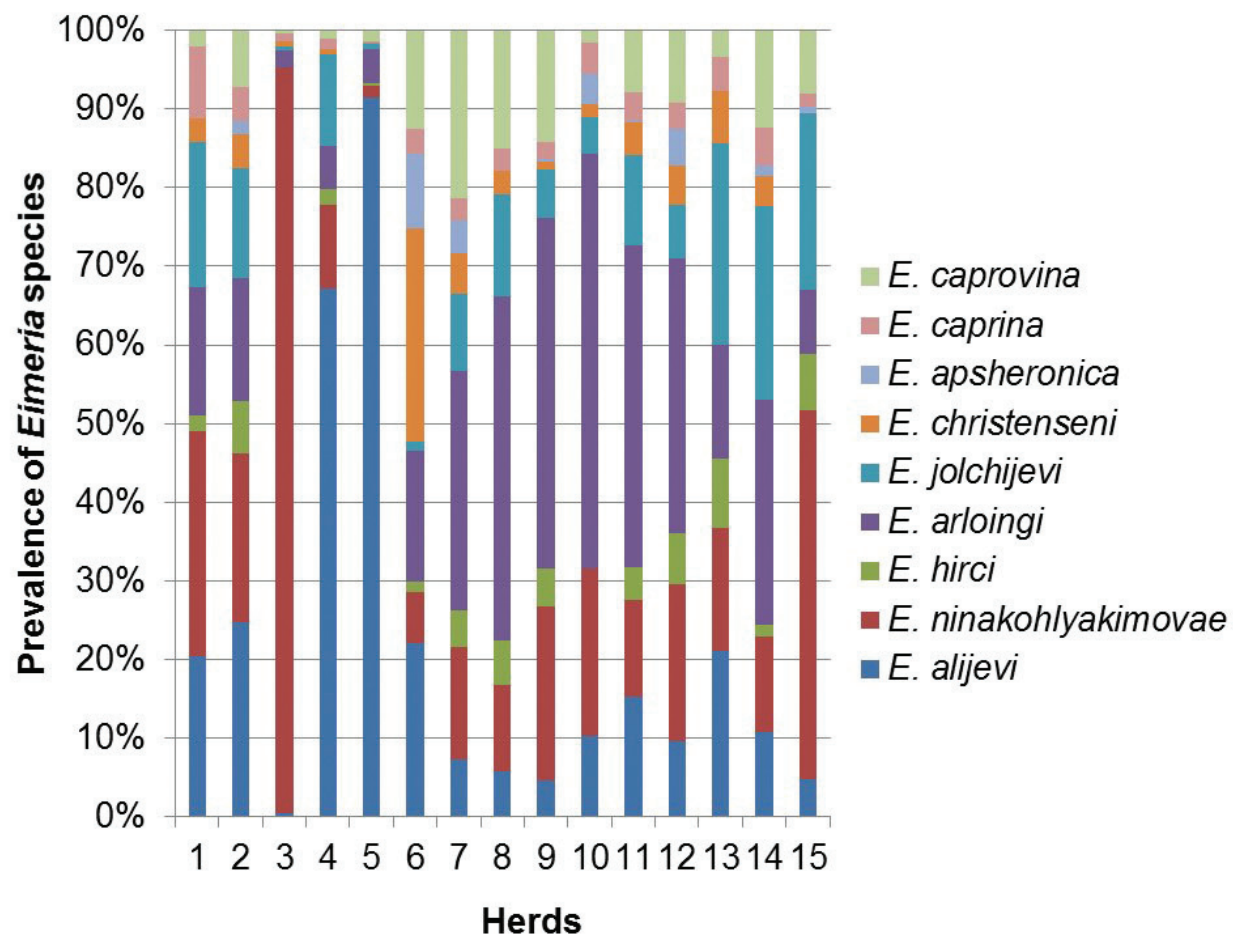

Figure 1. Prevalence of Eimeria species found in each Serpentina goat herd in Alentejo, Portugal. 


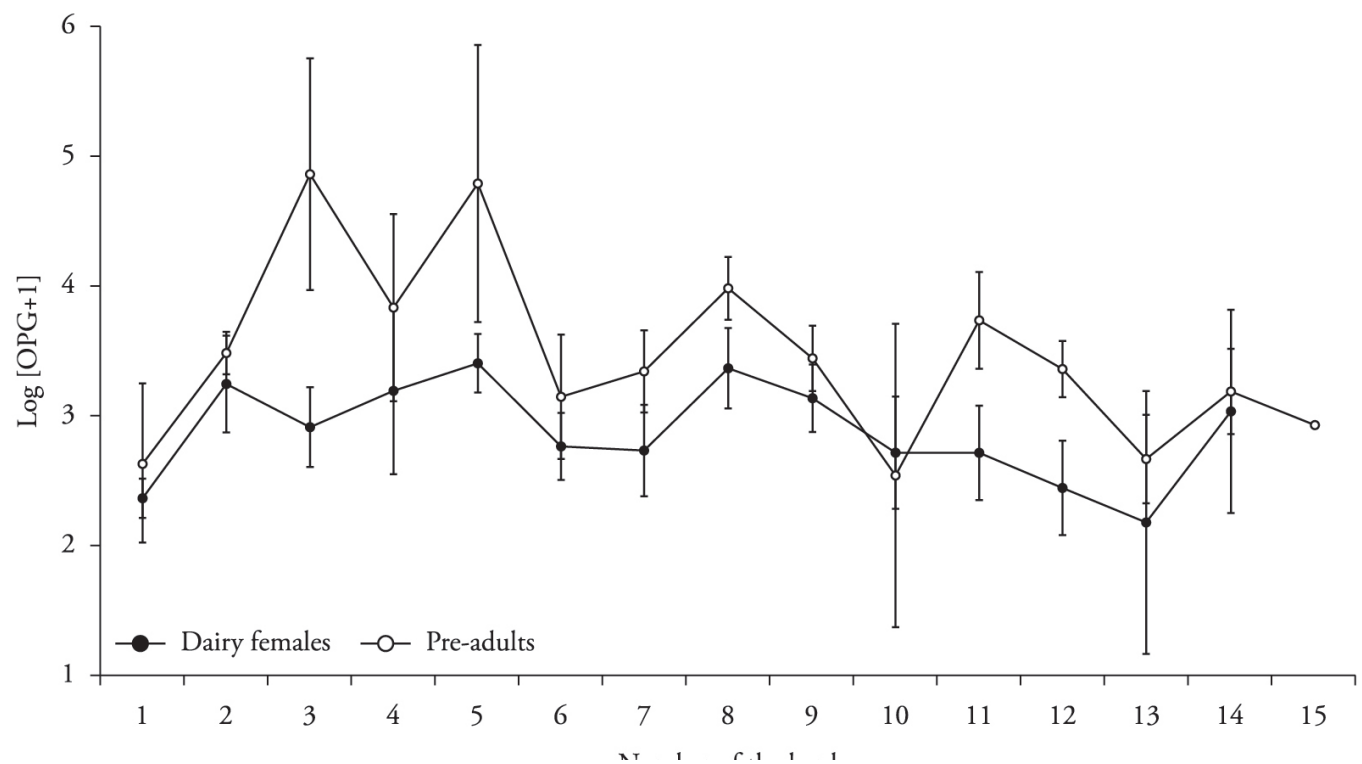

Figure 2. Eimeria spp. oocyst counts (oocysts per gram of feces, OPG) among dairy females and pre-adults in Serpentina goat herds in Alentejo, Portugal. Data are expressed as transformed values of $\log (\mathrm{OPG}+1)$.

low body weight and was found dead on the pasture. Although this animal was not part of the investigation owing to its young age, a necropsy was performed and contributed to this investigation, since it indicated that severe cases of caprine coccidiosis definitely occur in young goat kids within the herds examined. The OPG count of this affected animal was greater than $1 \times 10^{6}$ and the most frequent species found were E. arloingi (96.9\%), E. ninakohlyakimovae and E. caprovina (1.4\% each) and E. christenseni (0.3\%). At necropsy, pathological lesions similar to those reported for $E$. arloingi monoinfections in goats were found with large non-pedunculated to polyp-like whitish nodules, reaching the size of 3-5 $\mathrm{mm}$ within the jejunum and ileum (Figure 3A). Tissue alterations were characterized by hyperplasia of the intestinal villi and mild inflammation of the mucosa, on hematoxylin-eosin stained gut sections. Mucosal leukocyte infiltration mainly consisted of lymphocytes, eosinophils, polymorphonuclear neutrophils and macrophages, as well as plasma cells to a lesser extent. Different developmental stages of $E$. arloingi were found, including trophozoites, immature and mature first-generation macroschizonts, second-generation schizonts, macrogamonts, microgamonts, free microgametocytes and immature and mature oocysts (Figure 3B, C). Autolysis and necrosis of the affected villi were also observed, and the presence of necrotic epithelial cells and scattered developmental stages of the parasite were also seen within the lumen of the intestinal mucosa, as previously reported (HASHEMNIA et al., 2012). Bacterial infection was also observed in the affected gut lumen section.

\section{Discussion}

This study demonstrates that Eimeria species are widely distributed in the Serpentina goat herds of Alentejo, Portugal. The high prevalence of Eimeria infections found is consistent with previous reports from other regions experiencing comparable semi-arid climate conditions (DE LA FUENTE; ALUNDA, 1992;
RUIZ et al., 2006). Furthermore, the high OPG counts observed in pre-pubertal goats was consistent with previous age-related studies on caprine coccidiosis (PENZHORN et al., 1994; KOUDELA; BOKOVÁ, 1998). The infection intensity and frequency were lower in adult dairy goats, probably owing to previous exposure to Eimeria spp., thus resulting in partial protective immunity, in comparison with pre-pubertal goats. The two herds in which metaphylactic programs for caprine coccidiosis control were being conducted had OPG counts within the range of the non-treated animals. This showed that the treatment selected had failed and indicated that there was a need to improve the metaphylaxis method in order to achieve a reduction in oocyst shedding and thereby decrease the environmental contamination. As proposed by Ruiz et al. (2012), on goat farms with a history of serious clinical caprine coccidiosis, precise timing of treatments using the anticoccidial drug diclazuril improves the control over coccidiosis in the farm and prevents severe clinical status (RUIZ et al., 2012).

In general, adult animals are protected by cellular immune responses induced by primary Eimeria infections, in terms of clinical coccidiosis. However, this is not linked to complete interruption of internal parasite development, since these animals continue to shed Eimeria oocysts throughout their lives (TAYLOR; CATCHPOLE, 1994). This can be explained by the enzootic stability achieved between host and parasite, thus leading to nonclinical status among adult goats and even among pre-pubertal goats. In the current study, no significant differences in the OPGs between adult age ranges were found. In contrast to these findings, other studies have reported a slight increase in the excretion of oocysts among goats older than seven years of age, which has been interpreted as relative weakness of the host immune system (CHARTIER; PARAUD, 2012). Occasionally, host protective immune reactions against Eimeria infections fail due to adverse conditions, involving stress, dietary changes, prolonged travel, extremes of temperatures, weather conditions, environment 


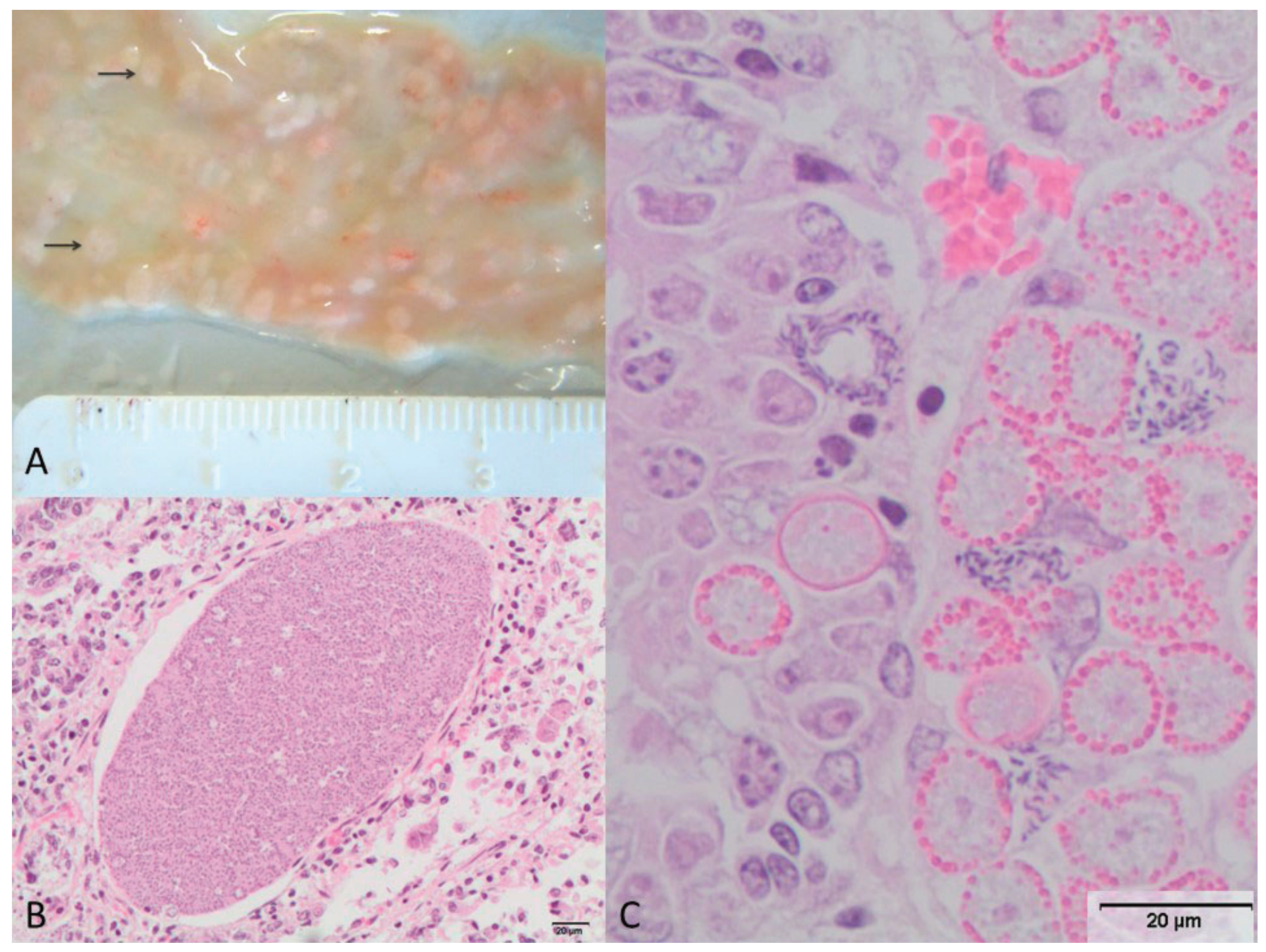

Figure 3. A. Jejunum. Natural infection of a two-month-old kid. Presence of scattered whitish pin-head size nodules (3-5 mm in diameter) (arrows). B. Multinucleated first-generation macroschizont. C. Cluster of macro and microgamonts and primitive oocyst.

changes, severe concomitant infections, nutritional status and other factors (TAYLOR; CATCHPOLE, 1994; DAUGSCHIES; NAJDROWSKI, 2005; RUIZ et al., 2006).

Eimeria ninakohlyakimovae and E. arloingi were the most predominant of the nine Eimeria species identified in the current study (Figure 2), which is in accordance to previous reports relating to other geographical areas (PENZHORN et al., 1994; AGYEI et al., 2004; RUIZ et al., 2006). These two species are well known as the most pathogenic species in cases of caprine coccidiosis (LEVINE, 1985; YVORÉ et al., 1985; KOUDELA; BOKOVÁ, 1998; CHARTIER; PARAUD, 2012). The general occurrence rate of $E$. christenseni was in agreement with previous studies, which also revealed higher prevalences among young goats than among adult dairy goats (LIMA, 1980; JALILA et al., 1998; HARPER; PENZHORN, 1999; HASSUM; MENEZES, 2005; RUIZ et al., 2006). Eimeria christenseni is considered to be one of the most pathogenic species in animals less than six months of age (AUMONT et al., 1984; LIMA, 2004). Nonetheless, other field surveys have shown very low prevalences of E. christenseni, not only in adults but also in young animals (KUSILUKA et al., 1996; AGYEI et al., 2004; FREITAS et al., 2005; CAVALCANTE et al.,
2012). These differences in prevalence may be attributed to varying geographical conditions (CHARTIER; PARAUD, 2012), e. g. $<7 \%$ prevalence of E. christenseni was found in Ghana (AGYEI et al., 2004), Spain (RUIZ et al., 2006) and Brazil (CAVALCANTE et al., 2012), whilst higher prevalence was observed in the United States (LIMA, 1980).

The pathological findings among the samples from the deceased two-month-old goat kid clearly indicated that E. arloingi was the prime cause of death and confirmed the high pathogenicity of this Eimeria species in young animals, as previously described (YVORÉ et al., 1985; KOUDELA; BOKOVÁ, 1998). Since this goat kid almost exclusively shed $E$. arloingi oocysts, this Eimeria species could even be considered to be a monocausal parasitic agent that led to the animal's death. However, because of the delayed discovery of this animal, it cannot be ruled out that the bacteria found in the histological analysis might have been a concomitant infection that was proven to aggravate the clinical outcome of coccidiosis in goat and poultry (NORTON, 1986; PRUKNER-RADOVCIC et al., 1995), or that invaded the mucosa after the animal's death. 
In conclusion, this survey clearly indicates that Eimeria infections are highly prevalent in Portugal, especially in Serpentina goats in the province of Alentejo. Although goats were affected by the most pathogenic species (e.g. E. ninakohlyakimovae, E. arloingi) and although pre-pubertal goats in particular shed high numbers of oocysts, no diarrhea, dirty posteriors or dehydration (symptoms commonly associated with caprine coccidiosis) were observed in any of the animals examined, which might indicate that there had been adequate development of protective cellular adaptive immunity against Eimeria spp.

Overall and compared with other livestock animals, goats are still a neglected species with regard to basic, clinical and epidemiological research. Nevertheless, these animals are the only reliable and economically viable source of meat and milk in certain climate areas. Foundations supporting research on caprine infections (e.g. CAPARA: COST action FA0805 of the European Community) currently pay tribute to the important value of this particular farm animal. Consequently, generation of epidemiological data on caprine Eimeria spp. will provide valuable data for future research on caprine coccidiosis.

\section{Acknowledgements}

This work was financed by FEDER funds through the Operational Program for Competitiveness Factors (COMPETE) and Portuguese funds through the Foundation for Science and Technology (FCT), within the Strategic Project PEst-C/AGR/ UI0115/2011. We would also like to thank the Portuguese Association of Serpentina Goat Farmers (APCRS) for kindly supplying samples and technical support during the fieldwork. L. M. R. Silva is a recipient of a FTC-funded PhD grant (BD/72032/2010).

\section{References}

Agyei AD, Odonkor M, Osei-Somuah A. Concurrence of Eimeria and helminth parasitic infections in West African Dwarf kids in Ghana. Small Rumin Res 2004; 51(1): 29-35. http://dx.doi.org/10.1016/S09214488(03)00184-6

Aumont G, Yvoré P, Esnault A. Experimental coccidiosis in goats. 1. Experimental model. Effects of parasitism on the feeding behaviour and the growth of animals; intestinal lesions. Ann Rech Vet 1984; 15(4): 46773. PMid:6529115.

Associação Portuguesa de Caprinicultores da Raça Serpentina - APCRS. Livro genealógico da raça [online]. Évora: APCRS; 2014 [cited 2014 Apr 17]. Available from: http://www.cabraserpentina.pt.

Cavalcante AC, Teixeira M, Monteiro JP, Lopes CW. Eimeria species in dairy goats in Brazil. Vet Parasitol 2012; 183(3-4): 356-8. PMid:21852038. http://dx.doi.org/10.1016/j.vetpar.2011.07.043

Chartier C, Paraud C. Coccidiosis due to Eimeria in sheep and goats, a review. Small Rumin Res 2012; 103(1): 84-92. http://dx.doi. org/10.1016/j.smallrumres.2011.10.022

Daugschies A, Najdrowski M. Eimeriosis in cattle: current understanding. $J$ Vet Med B Infect Dis Vet Public Health 2005; 52(10): 417-27. PMid:16364016. http://dx.doi.org/10.1111/j.1439-0450.2005.00894.x
Eckert J, Braun R, Shirley MW, Coudert P. Biotechnology: guidelines on techniques in coccidiosis research. COST 89/820. Luxembourg: Office for Official Publications of the European Communities; 1995.

Faizal AC, Rajapakse RP. Prevalence of coccidia and gastrointestinal nematode infections in cross bred goats in the dry areas of Sri Lanka. Small Rumin Res 2001; 40(3): 233-8. http://dx.doi.org/10.1016/S09214488(01)00179-1

Freitas FLC, Almeida KS, Nascimento AA, Machado CR, Veschi JLA, Machado RZ. Species of the genus Eimeria Schneider, 1875 (Apicomplexa: Eimeriidae) in dairy goats maintained in intensive system in the São José do Rio Preto region, São Paulo State, Brazil. Rev Bras Parasitol Vet 2005; 14(1): 7-10. PMid:16153337.

de la Fuente C, Alunda JM. A quantitative study of Eimeria infections of goats from central Spain. Vet Parasitol 1992; 41(1-2): 7-15. http:// dx.doi.org/10.1016/0304-4017(92)90003-R

Gabinete de Planeamento e Políticas - GPP. Animal production yearbook 2008/2009. Lisboa: GPP; 2009.

Harper CK, Penzhorn BL. Occurrence and diversity of coccidia in indigenous, Saanen and crossbred goats in South Africa. Vet Parasitol 1999; 82(1): 1-9. http://dx.doi.org/10.1016/S03044017(98)00266-0

Hashemnia M, Khodakaram-Tafti A, Razavi SM, Nazifi S. Experimental caprine coccidiosis caused by Eimeria arloingi: morphopathologic and electron microscopic studies. Vet Res Commun 2012; 36(1): 47-55. PMid:22127426. http://dx.doi.org/10.1007/s11259-011-9511-9

Hassum IC, Menezes RC. Natural infection with species of the genus Eimeria in small ruminant raised in two municipalities of the State Rio de Janeiro. Rev Bras Parasitol Vet 2005; 14(3): 95-100. PMid:16229752.

Hermosilla C, Barbisch B, Heise A, Kowalik S, Zahner H. Development of Eimeria bovis in vitro: suitability of several bovine, human and porcine endothelial cell lines, bovine fetal gastrointestinal, Madin-Darby Bovine Kidney (MDBK) and African green monkey kidney (VERO) cells. Parasitol Res 2002; 88(4): 301-7. PMid:11999015. http://dx.doi. org/10.1007/s00436-001-0531-1

Instituto Nacional de Estatística - INE. Statistical Yearbook of Alentejo Region 2010. Lisboa: INE; 2010.

International Union for Conservation of Nature - IUCN. The IUCN Red List of Threatened Species. Version 2013.2 [online]. Switzerland: IUCN, 2013 [cited 2014 Apr 17]. Available from: http://www. iucnredlist.org.

Jalila A, Dorny P, Sani R, Salim NB, Vercruysse J. Coccidial infections of goats in Selangor, peninsular Malaysia. Vet Parasitol 1998; 74(2-4): 165-72. http://dx.doi.org/10.1016/S0304-4017(97)00133-7

Kanyari PW. The relationship between coccidial and helminth infections in sheep and goats in Kenya. Vet Parasitol 1993; 51(1-2): 137-41. http:// dx.doi.org/10.1016/0304-4017(93)90204-Z

Koudela B, Boková A. Coccidiosis in goats in the Czech Republic. Vet Parasitol 1998; 76(4): 261-7. http://dx.doi.org/10.1016/S03044017(97)00147-7

Kusiluka LJM, Kambarage DM, Matthewman RW, Harrison LJS, Daborn CJ. Coccidiosis of small ruminants in Tanzania. Small Rumin Res 1996; 21(2): 127-31. http://dx.doi.org/10.1016/09214488(96)00860-7

Levine JD. Veterinary protozoology. Ames: ISU Press; 1985.

Lima JD. Prevalence of coccidian in domestic goats from Illinois, Indiana, Missouri and Wisconsin. Int. Goat Sheep Res 1980; 1: 234-41. 
Lima JD. Coccidiose dos ruminantes domésticos. Rev Bras Parasitol Vet 2004; 13(S1): 9-13.

Norton CC. Coccidia of the domestic goat Capra hircus, with notes on Eimeria ovinoidalis and E. bakuensis (syn. E. ovina) from the sheep Ovis aries. Parasitology 1986; 92(Pt 2): 279-89. PMid:3714300. http://dx.doi. org/10.1017/S0031182000064052

O'Callaghan MG. Coccidia of domestic and feral goats in South Australia. Vet Parasitol 1989; 30(4): 267-72. http://dx.doi.org/10.1016/03044017(89)90095-2

Penzhorn BL, Rognlie MC, Hall LL, Knapp SE. Enteric coccidia of Cashmere goats in southwestern Montana, USA. Vet Parasitol 1994; 55(1-2): 137-42. http://dx.doi.org/10.1016/03044017(94)90064-7

Programa de Desenvolvimento Rural - PRODER. Proteç̧ão da biodiversidade doméstica. Nota explicativa. Version V12.01.2011 [online]. Portugal: PRODER; 2011 [cited 2014 Apr 17]. Available from: http:// www.proder.pt/conteudo.aspx?menuid $=494$.

Prukner-Radovcic E, Milakovic-Novak L, Ivesa-Petricevic S, Grgic N. Clostridium chauvoei in hens. Avian Pathol 1995; 24(1): 201-6. PMid:18645777. http://dx.doi.org/10.1080/03079459508419060
Ruiz A, Gonzalez JF, Rodriguez E, Martín S, Hernández YI, Almeida $\mathrm{R}$, et al. Influence of climatic and management factors on Eimeria infections in goats from semi-arid zones. J Vet Med B Infect Dis Vet Public Health 2006; 53(8): 399-402. PMid:17010046. http://dx.doi. org/10.1111/j.1439-0450.2006.00985.x

Ruiz A, Behrendt JH, Zahner H, Hermosilla C, Pérez D, Matos L, et al. Development of Eimeria ninakohlyakimovae in vitro in primary and permanent cell lines. Vet Parasitol2010; 173(1-2): 2-10. PMid:20594648. http://dx.doi.org/10.1016/j.vetpar.2010.05.023

Ruiz A, Guedes AC, Munoz MC, Molina JM, Hermosilla C, Martín $S$, et al. Control strategies using diclazuril against coccidiosis in goat kids. Parasitol Res 2012; 110(6): 2131-6. PMid:22193521. http://dx.doi. org/10.1007/s00436-011-2746-0

Taylor MA, Catchpole J. Review article: coccidiosis of domestic ruminants. Appl Parasitol 1994; 35(2): 73-86. PMid:8087156.

Thienpont D, Rochette F, Van Parijs OFJ. Diagnosing helminthiasis through coprological examination. Beerse: Janssen Research Foundation; 1979.

Yvoré P, Esnault A, Naciri M. La coccidiose caprine: effets de contaminations mono ou multispécifiques. Rec Med Vet 1985; 161:347-1. 